原著

\title{
歯の健康診断の予備調査としての質問紙調査成績
}

\author{
山田茂* 相田孝 信** KOK YEN YIN*
}

概要：小学校児童 386 名を対象上して，歯の健康診断に先立つて質問紙による予備調查を行い，これ をその直後に行つた歯の健康診断と対比し次のような成績を得た。

1. 歯の健康診断の 予備調査のために，質問紙によつて，1）「このごろ，歯が，いたんだことがあ りますか」，2）「食べものがよくかめないと，おもつたことがありますか」，3）「歯ならびの，わるい ことを，いつも，気にしていますか」，4)「いつも，口をあけている，〈せが，ありますか」，歯ぐき から，血が，でやすいですか」の 5 問について回答を求めた。

2. 上記 $1 \cdot 3 \cdot 5$ 問は歯の健康診断の予備調査として役立つところが多いものと考えられる。

\section{Questionnaire Findings as a Preliminary \\ Survey to Oral Health Examinations}

By

Shigeru YAMADA,* Takanobu AIDA** and Kok Yen YIN*

Prior to regular oral health examinations, a total of 386 elementary school children were subjected to a survey by the use of questionnaires. Findings revealed by the questionnaires. were subsequently compared and studied with those findings obtained from actual oral health examinations which were conducted soon afterwards.

The following were salient conclusions arrived at.

1. The questionnaire form contained the 5 items of 1 ) if there was experienced a toothache in the immediate past, 2) if one thought that one could not chew food properly, 3) if one was conscious of the malalignment of one's teeth, 4) if one had a habit of keeping one's mouth open all the time, and 5 ) if the gum was easily susceptible to bleeding.

Subjective answers were asked to each of the items.

2. Of these 5 items contained in the questionnaires, items 1), 3) and 5) were though to be of much use to actural oral health examinations.

\section{緒言}

集団検査において時間と労力をできるだけ節約 し，しかも疾病を見落さないようにすることは重 要な要件である。そのための方法として質問紙に よる予備調查を行ない, 問診の助けとし, 要注意 者の発見に役立て，視診触診で見逃すことのある 健康に関する不安悩みなどの発見に役立てること
が考えられる。われわれは小学校児童を対象とし て歯の健康診断に先立つて質問紙による予備調査 を行ない，その効果について研究したので，その 概要を報告する。

\section{研究方法と研究対象}

研究対象は埼玉県南畑小学校児童の 1 学年から 6 学年までの約 500 名であつたが，記入の不備な

* 日本大学歯学部篹正学教室 (主任: 有田正俊教授)

Department of Orthodontics, Nihon University School of Dentistry (Director : Prof. Masatoshi Arita)

** 日本保青歯科協会

Japan Society for Constructive Dentistry (Nihon Hoikushika Kyokai), Tokyo.

昭和45年11月10日受付 
表 1 質問 紙

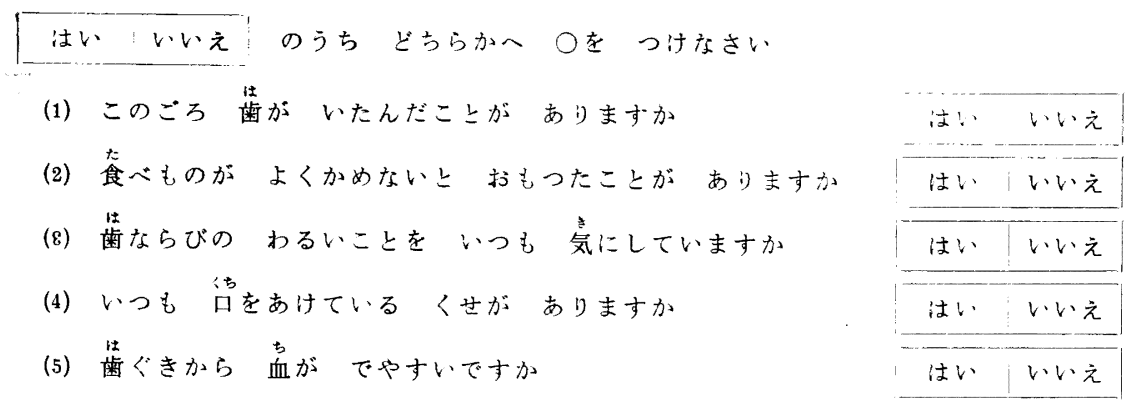

ものを除き，ここには 386 名について報告する。 質問紙は表 1 の 5 項目について児童に記入させた るのである。低学年の児童には 1 項目ごとに担任 教師に板書して説明してもらい，1項目うつ記入 させた。この内容は日本学校歯科医会が文部大臣 および文部省保健体育審議会長に提出した「学校 保健における 健康診断の方法改善に関する 要望 書」1に記載されたものと同じであつて，多少文 章の表現を小学校児童向けに変えただけである。 質問紙調查結果を，その直後に行なつた歯の検查 成績と対比し, 両者の関倸を追求した。

\section{研究成績}

質問紙調査 5 項目について，「はい」と答えたも のと「「いえ」と答えたものを比較し次のような 成績を得た。

1.「このごろ，歯が，いたんだことがあります か」という問に対する回答は表 2 のように「はい」 と答えたものは低学年に多い傾向を示している が，全学年では $23.8 \%$ であつた。これらの者につ いて, 乳歯永久歯の 1 人平均未処置歯数を求め,

両者を比較すると, $1 \cdot 3 \cdot 5 \cdot 6$ 学年は「はい」と 答えたものに多く，4学年は殆んど差がなく，2 学年は「はい」と答えたものに少なかつたが， 3 学年以外は有意の差がなく, 3 学年は $5 \%$ の危険 率で「はい」と答えたものに未処置歯数が多かつ た。また全学年についてみると $5 \%$ の危険率で 「はい」と答えたものに末処置歯数が多いことが認 められた。

2.「食べものが，よくかめないと，おもつた ことが，ありますか」という問に対する回答は表 3のように, 各学年とも「はい」と答えたものは
表 2 問「このごろ歯がいたんだことがありますか」 こ対なる「はい」「いいえ」の回答者別未処圈 歯数

\begin{tabular}{|c|c|c|c|c|c|c|}
\hline 区分 & はし & 上答えた & むの & いい & と答え & ももの \\
\hline 学年 & $\mathrm{n}$ & M & S D & $\mathrm{n}$ & $\mathrm{M}$ & S D \\
\hline 1 学年 & 25名 & 7.32歯 & 4.59 & 38名 & 6.58 歯 & 5.04 \\
\hline 2 & 15 & 5.83 & 3.93 & 48 & 6.08 & 3.95 \\
\hline 3 & 12 & $* 6.00$ & 3.11 & 49 & $* 4.12$ & 3.30 \\
\hline 4 & 11 & 3.46 & 2.52 & 48 & 3.48 & 2.60 \\
\hline 5 & 15 & 2.80 & 1.43 & 50 & 2.34 & 2.29 \\
\hline 6 & 16 & 1.68 & 2.14 & 61 & 1.25 & 1.51 \\
\hline $1 \sim 6$ & 92 & $* 4.86$ & 4.04 & 294 & *3.73 & 3.73 \\
\hline
\end{tabular}

備考:*印 $5 \%$ の危険率で有意, Mは乳歯・永久 歯の 1 人平均末処置歯数

表 3 問「食心゙ものが 上くかめないとおもつた ことがありますか」に対する「はい」「いい え」の回答者別未処置蒾数

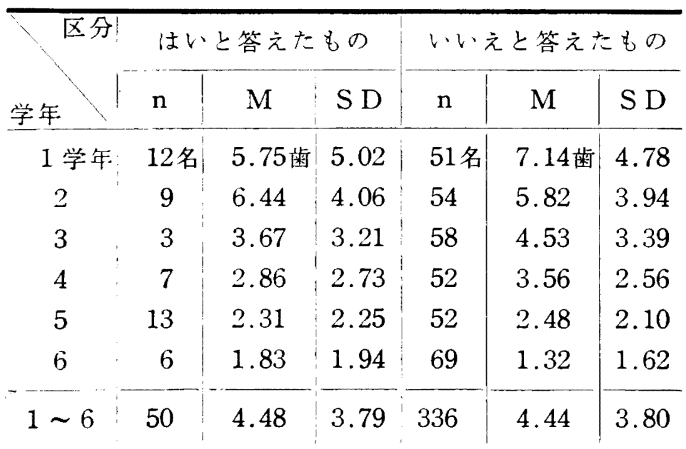

備考: M 乳歯・永久歯の 1 人平均未処置歯数

少なく，全学年の平均は $2.9 \%$ であつた。乳歯と 永久歯の 1 人平均未処置歯数を学年別にみると, 2.6 学年は「はい」と答えたものに, $1 \cdot 3 \cdot 4 \cdot 5$ 学年は「いいえ」と答えたものに多かつたが，各 
表 4 問「食べものが 上くかめない上 おもつた ことがありますか」に対する「はい」「いい え」の回答者別咬合状態

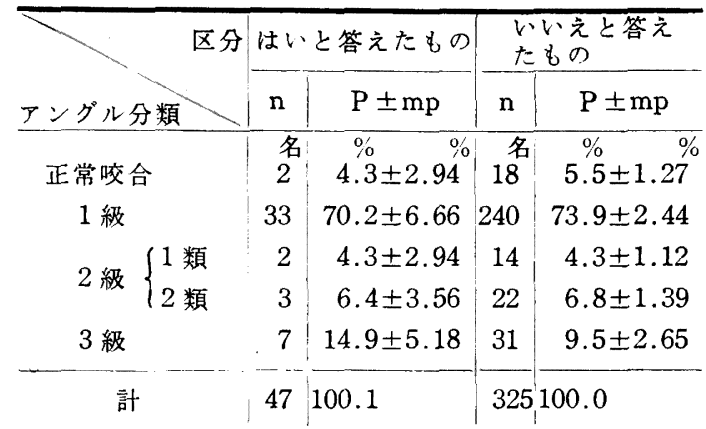

備考： $\mathrm{P}$ は百分率, $\mathrm{mp}$ はその平均誤差。以下同じ 学年とも有意の差を認め難く，全学年の平均は近 似し有意の差を認め難い。

咬合状態をアングル分類によつて比較してみる と，表4のように「はい」と答えたものと「いい え」と答えたものの間には有意の差を認め難い。 この第 2 問については，末処置歯数と咬合状態の 2 つの面からみる限り差はないもののようであ る。

3.「歯ならびの, わるいことを, いつも気にし ていますか」という問に対する回答者は表 5 のよ らに，「はい」と答えたものが $1 \cdot 2$ 学年に多い傾 向を示し，全学年では約16\%であつた。これらを 歯列の外観によつて良，中，不良の3 階級に分け てみると，表 5 のよに，1・2 学年では「不良」 には有意の差がなく，3学年では「はい」と答え たものに「不良」が 1 名もなかつた。しかしなが ら，4・5・6 学年と全学年では有意差をもつて「は
表 6 問「歯ならびの わるいことをいつも 気 にしていますか」に対する「はい」「いいえ」 の回答者別アングル分類

\begin{tabular}{|c|c|c|c|c|}
\hline \multirow{2}{*}{ アングル分類 } & \multicolumn{2}{|c|}{ はいと答えたもの } & \multicolumn{2}{|c|}{$\begin{array}{l}\text { いいえと答え } \\
\text { たもの }\end{array}$} \\
\hline & $\mathrm{n}$ & $\mathrm{P} \pm \mathrm{mp}$ & $\mathrm{n}$ & $\mathrm{P} \pm \mathrm{mp}$ \\
\hline 正常咬合 & $\begin{array}{l}\text { 名 } \\
2\end{array}$ & $3.5 \pm 2.39$ & 18 & $6.4 \pm 1.38$ \\
\hline 1 級 & 29 & $68.4 \pm 6.18$ & 233 & $74.4 \pm 2.46$ \\
\hline 和 1 類 & 2 & $3.5 \pm 2.39$ & 14 & $4.2 \pm 1.14$ \\
\hline 2 敉 $\{2$ 類 & 5 & $8.8 \pm 3.74$ & 20 & $6.4 \pm 1.38$ \\
\hline 3 級 & 9 & $15.8 \pm 4.82$ & 28 & $8.6 \pm 1.58$ \\
\hline 計 & 57 & 100.0 & 313 & .0 \\
\hline
\end{tabular}

い」と答えたものに「不良」が多かつた。これを 「良」に属するものについてみると， $1 \cdot 2 \cdot 3$ 学年 では「はい」と答えたものの中に「良」が $12 \sim 50$ \%あつたが，4・5・6学年では皆無であつた。以 上から 3 学年以下では歯列不正を気にしているも のが少なく，4 学年以上になつて 歯列不正を気に しているもののようである。しかしながらアング ル分類についてみると，表 6 のように各学年およ び全学年とも有意の差を認め難いが，3 級は「は い」と答えたものに多い傾向を示していた。また 各個人についてみると，個人差が著しく多く，一 般に男子はアングル 分類 2 級に「いいえ」と答え たものが多い傾向を，女子は 3 級に「はい」と答 えたものが多い傾向が認められた。また歯科学的 見地からは軽度の不正咬合であつても，当人は劣 等感を持つているものが 5 学年の女子に 1 名, 6 学年の男子に 1 名認められた。

4.「いつも， ロをあけている，くせが，あり

表 5 問「歯ならびの わるいことをいっも 気にしていますか」に対する「はい」 「いいえ」の回答者別歯列状態（良，中，不良の 3 度分類）

\begin{tabular}{|c|c|c|c|c|c|c|c|c|}
\hline \multirow[t]{2}{*}{ 区分 } & \multicolumn{4}{|c|}{ はいと答えたもの } & \multicolumn{4}{|c|}{ いいえと答えたもの } \\
\hline & $\mathrm{n}$ & $\begin{array}{c}\text { 良 } \\
\mathrm{P} \pm \mathrm{mp}\end{array}$ & $\begin{array}{c}\text { 中 } \\
\mathrm{P} \pm \mathrm{mp}\end{array}$ & $\begin{array}{c}\text { 不良 } \\
\mathrm{P} \pm \mathrm{mp}\end{array}$ & $\mathrm{n}$ & $\begin{array}{c}\text { 良 } \\
\mathrm{P} \pm \mathrm{mp}\end{array}$ & $\begin{array}{c} \\
\mathrm{P} \pm \mathrm{mp}\end{array}$ & $\begin{array}{c}\text { 不良 } \\
\mathrm{P} \pm \mathrm{mp}\end{array}$ \\
\hline 1 学年 & $\begin{array}{l}\text { 名 } \\
15\end{array}$ & $33.3^{\%} \pm 12.2^{\%}$ & $40.0^{\%} \pm 12.7^{\%}$ & $26.7^{\%} \pm 11.4^{\%}$ & $\begin{array}{l}\text { 名 } \\
48\end{array}$ & $20.8^{\%}+5.9^{\%}$ & $56.3^{\%} \pm 7.2^{\%}$ & $22.9^{\circ} \pm 6.1^{\circ}$ \\
\hline 2 & 16 & $12.5 \pm 8.3$ & $62.5 \pm 1.11$ & $25.0 \pm 10.8$ & 45 & $4.4 \pm 3.1$ & $84.4 \pm 5.4$ & $11.1 \pm 4.7$ \\
\hline 3 & 4 & $50.0 \pm 25.0$ & $50.0 \pm 25.0$ & 0 & 55 & $40.0 \pm 6.6$ & $50.9 \pm 6.7$ & $9.1 \pm 3.9$ \\
\hline 4 & 10 & 0 & $70.0 \pm 14.5$ & $30.0 \pm 14.5$ & 47 & $17.0 \pm 5.5$ & $74.5 \pm 6.4$ & $8.5 \pm 4.1$ \\
\hline 5 & 7 & 0 & $42.9 \pm 18.7$ & $57.1 \pm 18.7$ & 58 & $25.9 \pm 5.8$ & $55.2 \pm 2.5$ & $18.9 \pm 5.2$ \\
\hline 6 & 7 & 0 & $28.6 \pm 17.1$ & $71.4 \pm 17.1$ & 66 & $31.8 \pm 5.7$ & $50.0 \pm 6.2$ & $18.2 \pm 4.7$ \\
\hline $1 \sim 6$ & 59 & $15.25 \pm 4.68$ & $50.85 \pm 6.51$ & $32.90 \pm 6.16$ & 319 & $24.45 \pm 2.41$ & $60.50 \pm 2.73$ & $15.05 \pm 2.01$ \\
\hline
\end{tabular}


表 7 問「いつも 口をあけているくせがあり ますか」に対する「はい」「いいえ」の回答者 別アングル分類

\begin{tabular}{|c|c|c|c|c|}
\hline 区 & まい & と答えたもの & & $\begin{array}{l}\text { いえと答え } \\
\text { もの }\end{array}$ \\
\hline アングル分類 & $\mathrm{n}$ & $\mathrm{P} \pm \mathrm{mp}$ & $\mathrm{n}$ & $\mathrm{P} \pm \mathrm{mp}$ \\
\hline 正常咬合 & $\begin{array}{l}\text { 名 } \\
1\end{array}$ & \begin{tabular}{cr|}
$\%$ & $\%$ \\
$4.3 \pm$ & 4.25
\end{tabular} & $\begin{array}{l}\text { 名 } \\
19\end{array}$ & $5.5^{\circ} \pm 1.22^{\%}$ \\
\hline 1 級 & 13 & $56.5 \pm 10.35$ & 259 & $74.4 \pm 2.34$ \\
\hline 2 級 $\int 1$ 類 & 3 & $13.0 \pm 7.03$ & 14 & $4.0 \pm 1.05$ \\
\hline 2 政 $\{2$ 類 & 4 & $17.4 \pm 7.91$ & 20 & $5.7 \pm 1.24$ \\
\hline 3 級 & 2 & $8.7 \pm 5.86$ & 36 & $10.3 \pm 1.63$ \\
\hline 計 & 22 & 99.9 & 348 & 99.9 \\
\hline
\end{tabular}

表 8 問「歯ぐきから 血が でやすいですか」に 対する「はい」「いいえ」の回答者別PMA指数

\begin{tabular}{|c|c|c|c|c|c|c|}
\hline 区分 & \multicolumn{3}{|c|}{ はいと答えたもの } & \multicolumn{3}{|c|}{ いいえと答えたもの } \\
\hline 学年 & $\mathrm{n}$ & M & S D & $\mathrm{n}$ & M & S D \\
\hline 1 学年 & 8名 & $* 2.50$ & 2.02 & 73名 & 0.48 & 1.23 \\
\hline 2 & 4 & 2.00 & 1.14 & 70 & 20.1 & 1.51 \\
\hline 3 & 10 & $* 4.70$ & 3.81 & 61 & 2.44 & 2.01 \\
\hline 4 & 5 & * 6.40 & 2.30 & 66 & 2.22 & 2.40 \\
\hline 5 & 12 & ** 9.08 & 4.57 & 82 & 4.10 & 1.07 \\
\hline 6 & 6 & $* * 12.00$ & 3.50 & 76 & 5.58 & 3.45 \\
\hline $1 \sim 6$ & 45 & ** 7.53 & 2.74 & 428 & 2.71 & 2.14 \\
\hline
\end{tabular}

備考: * 印 $5 \%$ の危險率で有意, **印 $1 \%$ の殸 険率で有意。

ますか」という問に対する回答者は，表 7 のよう に「はい」と答えたものが 2 学年に多い傾向を認 めたが，学年による 差は少なく，4.6〜11.3\%で あつた。アングル分類についてみると，「はい」と 答えたものに 2 級 1 類が多い傾向を認めたが，学 年別にみても，全学年についてみても有意の差を 認めなかつた。耳鼻科疾患については, 学校の健 康診断票に記載されているものについては例数が 少なく, 内容の明かでないものもあつて比較が困 難であつた。

5.「歯ぐきから，血が，でやすいですか」とい う問に対する回答者は表 8 のように，「はい」と答 えたもの45名，「いいえ」と答えたもの 428 名で, これらのものについて PMA 指数を比較してみる と，2 学年には殆んど差がなかつたが，2学年以 外のすべての学年は「はい」と答えたものに有意
の差をもつて PMA 指数が多く, 全学年平均では $1 \%$ 危険率で「はい」と答えたものに PMA 指 数が多いことが認められた。

\section{総括と考案}

多数の人々の健康診断を行なう場合，できるだ け時間，労力を節約し，しかもできるだけ精度の 高い診断を行なうことが要求される。これを満足 させる方法としてスクリーニング・テスト方式が 取入れられている。 日本に㧍ける小学校の健康 診断においても，1971年からスクリーニング・テ ストの考え方と方式が取入れられることが明らか にされた。スクリーニングテストにおいては医 師，歯科医師の労力と時間をできるだけ省略し， 技術者などによる予備検査あるいは第 1 次スクリ ーニグンの方法が考えられている。たとえば胸部 $\mathrm{X}$ 線間接撮影検査, ツベルクリン反応検查, 寄生 虫検查, 聴力検查, 色覚検査などがそれである。 歯科領域においても第 1 次スクリーニングに適当 な满蝕活動性試験法，オルソ・パントモグラフの ような方法もあるが，現時点で一般に使用するこ とは困難である。またスクリーニング・テストの 予備調查として質問紙調査を行ない，問診の補助 とし，要注意者の発見に役立て，あるいは健康診 断の際見落しやすい健康に関する悩み, 不安, 欲 求などを知る方法が考えられている。従来健康診 断のための質問紙調査法として使用されているも のには, 神経症徵候検査のための NST (Neurosis screening test), MNPI (Minnesota multiphasic personality invent）などがあり，自覚症状の質問 によつて臨床診断に役立てるものとしては Cornell 大学医学部の Brodman, K., Erdmann, A. J., and Wolff, H. G. によつて創案された CMI (Cornell medical index) が広く応用されている。 CMI の研究調査報告は多くたとえば Stout, C., Wight, M. A., and Bruhn, J. G. ${ }^{2)}$ など報告が ある。CMI は身体的自覚症状の質問154項目, 精 神的自鸴症状の質問51項目からなり，この中に含

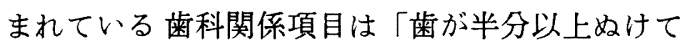
いますか」，「歯ぐきから血がでてこまりますか」, 「歯のひどい痛みに悩まされることがありますか」 
の3つである。これらは主として成人を対象とし たものであつて, 前記日本学校歯科医会の「学校 保健における歯科健康診断の方法改善に関する要 望書」にあるアンケート調査も，この CMI を参 考にして小学校児童に 適用できるようにしたもの のようである。小学校児童の歯の健康診断に先立 つて，質問紙による予備調査を行なつた例は極め て少ないもののようであり，そのような報告は見 当らなかつた。われわれは歯の健康診断に先立つ て行なう質問紙調査がどのような効果を持つかを 研究し, 将来のスクリーニング・テストの参考に したいと考えこの調査を行なつたものである。そ の結果，第 1 問の「このごろ歯が，いたんだこと がありますか」という問は未処置歯数が多いであ ろうという予測ができ，最近痛みを伴なつている ことが予測できるという点で歯の 健康診断と保健 指導に役立つものと考えられる。第 3 問の「歯な らびの，わるいことを，いっも，気にしています か」といら問は，歯列の外観の悪いことを気にし ているという予測, および矯正歯科学の立場から みて軽度の不正咬合であつても，児童には劣等感 をもたらす場合の発見に役立つことが明らかであ る。したがつて第 3 問は予備調查として有意であ ると考えられる。第 5 問の「歯ぐきから，血が, でやすいですか」という問は，「はい」と答えたも のが，「いいえ」と答えたものより高度の有意性を もつて PMA 指数の多いことが認められる。第 5 問は小学校児童において見落されやすい歯肉炎 の発見に役立つものと考えられる。第 2 問の「食
ベものが、よくかめないと、おもつたことが、あ りますか」，第 4 問の「いつも，口をあけている， くせが，ありますか」の問はその有益性に疑問が ある。

質問紙の回答は担任教師の十分な 指導のもとに 記入させたが，第 1 問については 2 学年，第 2 問 については $1 \cdot 2$ 学年，第 5 問については 2 学年 の理解が不十分であつたようである。低学年にお いては児童自身と保護者の両方から回答を求める ことが必要な場合もあると考えられる。

以上からこれを総括すると，

1）歯の健康に 関するスクリーニング・テスト の予備調查として, 質問紙調査は有益である。

2）質問内容は，本調查の範囲では「このごろ 歯が，いたんだことが，ありますか」，「歯ならび の，わるいことを，いつも気にしていますか」， 「歯ぐきから，血がでやすいですか」の 3 項目が有 益であると考えられる。

3）小学校低学年児童の回答には，質問の意味 を十分理解していない場合があると考えられる。

\section{文 献}

1) 日本学校歯科医会：学校保健论衫る歯科健康 診断の方法改善に間する要望書, 日本学校歯科 医会会誌，16号：103-105，1970.

2) Stout, C., Wight, M. A. and Bruhn, J. G. : The Cornell medical index in disability evaluation, Brit. J. prev. soc. Med., 23 : 251$254,1969$. 